\title{
Elaboration, evaluation of nutritional information and physical-chemical stability of dairy fermented drink with caja-mango pulp
}

\author{
Handray Fernandes de Souza $^{1}$ (D) Lara Aguiar Borges ${ }^{1}$ (D) João Pedro Antunes Lopes ${ }^{1}$ (iD \\ Bruna Mara Aparecida de Carvalho ${ }^{1}$ (iD) Sérgio Henrique Sousa Santos ${ }^{1}$ (iD \\ Anna Christina de Almeida ${ }^{1}$ (D) William James Nogueira Lima ${ }^{1}$ (D) Igor Viana Brandi $^{*}$ (iD)
}

'Instituto de Ciências Agrárias, Universidade Federal de Minas Gerais (UFMG), Campus Regional de Montes Claros, 39404-547, Montes Claros, MG, Brasil. E-mail: ibrandi@hotmail.com. "Corresponding author.

ABSTRACT: Whey is a by-product of the dairy industry of great importance due to its high nutritional value, and can be used for the manufacture of fermented dairy drinks which, combined with fruit, increase the nutritional value and add characteristic flavors. Therefore, a fermented dairy beverage with caja-mango pulp (Spondias dulcis) was elaborated and its nutritional information as well as the physicalchemical stability were evaluated during storage. The results showed that the nutritional information met the requirements stipulated by the Brazilian legislation. The physical-chemical stability of the dairy fermented drink in terms of $p H$, acidity, syneresis and sedimentation was influenced by the storage time, possibly associated with uncontrolled factors in this study, such as the initial and final dairy culture concentration of the processed product, protein biodegradation during storage and low solids contents. It is concluded that the elaborated drink constitutes a food source of several nutrients, and may complement the daily diet of children, adolescents and adults, supplying nutritional deficiencies. Key words: whey, dairy industry, nutritional value, Spondias dulcis.

Elaboração, avaliação de informação nutricional e estabilidade físico-química de bebida láctea fermentada com polpa de cajá-manga

RESUMO: O soro lácteo é um subproduto da indústria de laticínios de grande importância devido ao seu alto valor nutritivo, podendo ser utilizado para fabricação de bebida láctea fermentada que, associada a frutas, aumenta o valor nutricional e agrega sabores característicos. A partir disso, foi elaborada uma bebida láctea fermentada adicionada de polpa de cajá-manga (Spondias dulcis), sendo avaliada sua informação nutricional bem como a estabilidade fisico-química, durante o armazenamento. Os resultados mostram que a informação nutricional atendeu os requisitos estipulados pela legislação brasileira. A estabilidade fisico-química da bebida, quanto aos parâmetros analisados de pH, acidez, sinerese e sedimentação, sofreu influência pelo o tempo de armazenamento, possivelmente, associados a fatores não controlados neste estudo como a concentração de cultura láctea iniciadora e final do produto elaborado, a biodegradação de proteínas durante a estocagem e baixos teores de sólidos. Conclui-se que a bebida elaborada constitui um alimento fonte de diversos nutrientes, e poderá complementar a alimentação diária de crianças, adolescentes e adultos, suprindo as carências nutricionais.

Palavras-chave: soro lácteo, indústria de laticínios, valor nutricional, Spondias dulcis.

\section{INTRODUCTION}

Considered as a by-product of the dairy industries, the whey has shown great importance due to their high nutritional value (ALMEIDA et al., 2001; MONTESDEOCA et al., 2017). Being a food made up of water, lactose, proteins, lipids, vitamins and minerals has been used in the elaboration of dairy drinks, proving to be a rational form of utilization in the dairy industry (CALDEIRA et al., 2010; MONTESDEOCA et al., 2017). Moreover, it is seeing that, in the last years, the production of dairy fermented drink has been gaining market share in reason of their good sensorial acceptation, low production price and more accessible prices for the consumer (THAMER \& PENNA, 2006; CALDEIRA et al., 2010; JANIASKI et al., 2016).

According to Normative Ruling $\mathrm{n}^{\mathrm{o}}$ $16 / 2005$, which deals with the technical regulation of identity and quality of milk drink, milk beverage is the dairy product resulting from the mixture of milk and whey, whether or not added food products or substances, vegetable fat and other milk products, where the dairy base (whey and milk) accounts for at least $51 \%$ of total ingredients (BRASIL, 2005a). Conversely, fermented milk drinks can be obtained by 
adding a specific culture of microorganisms or by adding fermented milk to the formulation (BRASIL, 2005a).

According ZULUETA et al. (2007), the dairy fermented drink can be associated with fruits, increasing the nutritional value and still adding characteristics flavors, thus, awakening sensorial characteristics that resemble yoghurt and nonfermented dairy drinks, so they are well marketed.

The caja-mango fruit (Spondias dulcis), have pleasant smell and taste, yield over than $60 \%$ in pulp and is highly used on the elaboration of juices, jelly, nectar, ice creams and some beverages like wines and liquors (BUSANELLO, 2014). However, due to their acidity, it isn't appreciated or few appreciated in natura (RUFINO, 2008). Nevertheless, the caja-mango pulp has been aroused interest of many regions of Brazil, as it is not too thick around the voluminous core, juicy, acid flavor, sugary and very pleasurable. It is rich in sugar, carotenoids and Vitamin C (SACRAMENTO \& SOUZA, 2000).

For present good nutritional and sensorial characteristics, and having attracted the interest of processing industries for the low manufacturing cost and which seeking to developed health products with differential tastes, this article had as aim to elaborate, to evaluate nutritional information, physicalchemistry stability of dairy fermented drink added with caja-mango pulp, along the storage.

\section{MATERIALS AND METHODS}

The dairy production was made at the Food Technology Laboratory of Science Agricultural Institute of Minas Gerais Federal University, according ALMEIDA et al. (2001) methodology, with modifications.

The ingredients of the elaborated dairy were whole milk $(39.04 \%)$, whey reconstituted $(39.04 \%)$, sugar $(10.00 \%)$ and modified starch $(0.80 \%)$. This first mixture received heat treatment $\left(65^{\circ} \mathrm{C}\right.$ by 30 minutes), with subsequent cooling $\left(43^{\circ} \mathrm{C}\right)$ and inoculation of Direct Vat Set (DVS) thermophilic $(1.00 \%)$ acid lactic culture with a mix of Streptococcus thermophilus and Lactobacillus delbrueckii subsp. bulgaricus strains. After this step, the blend was incubated at $43{ }^{\circ} \mathrm{C}$ on BOD oven (EL202/4E model) until reaching the casein isoeletric point $(\mathrm{pH} 4.60)$ and the curd formation. After that, was did the cooling at $5{ }^{\circ} \mathrm{C}$ by 5 hours. The dairy fermented drink was agitated and the pasteurized pulp fruit $(10.00 \%)$, potassium sorbate $(0.12 \%)$ were added with posterior homogenization. The dairy was bottled and stored under refrigeration $\left(5^{\circ} \mathrm{C}\right)$.
In order to recognize the nutritional quality, the nutritional information of the fermented dairy beverage was elaborated, based on the formulation used and Resolution RDC 360/2003, which deals with the obligatory nutritional labeling for packaged foods (BRASIL, 2003), and Resolution RDC n ${ }^{\circ}$ 269/2005, which deals with the Recommended Daily Intake of proteins, vitamins and minerals (BRASIL, 2005b).

The $\mathrm{pH}$ analyzes were performed by direct measurements in $\mathrm{pH}$ meter (PHS-3E model) and titratable acidity (titrator method) according to the methodology of BRASIL (2006).

The syneresis index was determined using the methodology described by AMAYA-LLANO et al. (2008) with modifications. Samples of $2 \mathrm{~g}$ were weighed and conditioned in microcentrifuge tubes (model SL-5AM), and centrifuged at $8000 \mathrm{rpm}$ for 10 minutes at $25{ }^{\circ} \mathrm{C}$. The supernatant was removed and weighed. The syneresis index, expressed as a percentage $(\%)$, was obtained by the ratio of the mass of the supernatant (whey) to the total mass of the sample multiplied by 100 .

For the sedimentation analysis, we used the method described by WHITE et al. (2008) with modifications. Thus, $10 \mathrm{~g}$ of samples were weighed and packed in hermetically sealed cylindrical plastic tubes, refrigerated at $5 \pm 1{ }^{\circ} \mathrm{C}$ for 72 hours. The percent sedimentation rate $(\%)$ was determined by the ratio of sediment mass to total sample mass, multiplied by 100 .

The analyzes were carried out in triplicate in the samples stored under refrigeration at $5 \pm 1{ }^{\circ} \mathrm{C}$. Results were tabulated and submitted to analysis of variance (ANOVA) and Tukey's test for average difference at $95 \%$ confidence $(\mathrm{P} \leq 0.05)$, with the support of Software R version 2.11.1 (R Development Core Team - 2010).

\section{RESULTS AND DISCUSSION}

The nutritional information of the fermented dairy beverage is presented in table 1 . The general requirements for nutritional information stipulated by Resolution RDC 360/2003 have been verified and attend the requirements. According the same resolution the energy value and the percentual of diary value (\% DV) must be declared in whole numbers (BRASIL, 2003).

According the table 1, the dairy beverage presents significant amounts of carbohydrates (34 g), proteins $(4.0 \mathrm{~g})$ and total fats $(2.4 \mathrm{~g})$ for a $200 \mathrm{~mL}$ portion of liquid product, because according BRASIL (2003) with amounts of $0.5 \mathrm{~g}$ or less than per portion 
Table 1 - Nutritional information of fermented dairy drink produced.

\begin{tabular}{|c|c|c|}
\hline & Quantity portion & $\% \mathrm{VD}^{*}$ \\
\hline Energetic Value & $174 \mathrm{kcal}=731 \mathrm{~kJ}$ & 9 \\
\hline Carbohydrates & $34 \mathrm{~g}$ & 11 \\
\hline Proteins & $4.0 \mathrm{~g}$ & 5 \\
\hline Total fat & $2.4 \mathrm{~g}$ & 4 \\
\hline Saturated fat & $1.6 \mathrm{~g}$ & 7 \\
\hline Trans fats & $* * *$ & ** \\
\hline Food Fibers & *** & *** \\
\hline Sodium & $159 \mathrm{mg}$ & 7 \\
\hline Calcium & $199 \mathrm{mg}$ & 25 \\
\hline Ferro & $7 \mathrm{mg}$ & 49 \\
\hline
\end{tabular}

*Daily Values (DV) of reference on basis at a diet with $2000 \mathrm{kcal}$ (kilocalories) or $8400 \mathrm{~kJ}$ (kilojoules).

Those values can be bigger or smaller depend on your energy needs.

*** Daily values not established.

${ }^{* * *}$ Zero or don't contain significant amounts.

of the said nutrients, will be declare "zero" or "does not contain" meaning amounts.

The significant value of carbohydrates shows as a positive aspect due to the presence of that nutrient in appropriates concentration on foods became important, since they are nutrients that, among others functions constitute as the main source of energy on human dietary and also as a determinant factor of post-meal blood glucose levels in the body (GIACCO et al., 2016). In other way, the proteins values shows too as an important data, since that for the body human it is one of the essentials macronutrients which constitute about of half human dry weight. Beyond that, the many amino acids like lysine, methionine and tryptophan which are proteins components are essentials for the growth, tissue repair and substitution, can even be used as source of energy (DAY, 2016).

In relation of total fats content (Table 1), the elaborated beverage was a food with lower fat content, because presented $2.4 \mathrm{~g}$ of total fat per $200 \mathrm{~mL}$ and according BRASIL (1998), to be considered a food with low value of fat, should present at maximum $1.5 \mathrm{~g}$ of fat by a portion of $100 \mathrm{~mL}$ of liquid product. Besides that, in relation to saturated fat and trans fat amounts, the dairy has significant amounts of saturated fat, as it has a value of $1.6 \mathrm{~g}$ for a $200 \mathrm{~mL}$ portion of liquid product, which according to BRAZIL (2003), if the quantity of this component is less than or equal to $0.2 \mathrm{~g}$ per $100 \mathrm{~mL}$ portion of liquid product, it will be declared on the label as "zero" or "does not contain" significant quantities. However, fats can't be considered as a negative aspect, because are macronutrients responsible for $35 \%$ off total caloric intake, especially on the triacylglycerols form. Also, fats can increase palatability of food products and provides essential fatty acids (LUCA, 2019).

According to BRASIL (1998), the minimum value for a liquid product to be classified as a fiber source is $1.5 \mathrm{~g}$ of fibers per $100 \mathrm{~mL}$ of liquid product. However, dietary fiber levels were not identified for the elaborated beverage, as presented in table 1 .

For sodium, the elaborated fermented milk beverage presented with low contents according to BRASIL (1998), which stipulates as "low" the maximum of $120 \mathrm{mg}$ of sodium in $100 \mathrm{~mL}$ of liquid product. The low values of sodium are important once exist an intense preoccupation with reduction of salt $\mathrm{n}$ industrialized foods. Although, the presence of sodium in rights concentrate o food is exceptional for the nutrients absorption on small intestine as well for maintenance of the celular membrane potential (KLOSS et al., 2015).

For calcium, its presence can be considered as a positive aspect, as it is involved in a wide range of life functionalities, through the interaction between several proteins distributed in different cell compartments. This macroelement is essential for muscle contraction, cell differentiation, immune response, enzymatic activation as well 
as neuronal activity and programmed cell death (CHEN et al., 2012; ZHAO et al., 2012; ZHONG et al., 2013; ZHANG et al., 2014; ZHANG \& ZOWALATY, 2016).

Moreover, according to the nutritional information presented in table 1 , it is possible to observe that the elaboration of the fermented milk drink, added with cashew mango pulp, constitutes a source food of several nutrients.

The physical-chemical stability of the elaborated dairy beverage was evaluated for $\mathrm{pH}$, acidity, syneresis and sedimentation parameters during 14 days of refrigerated storage. The results of $\mathrm{pH}$ and acidity during storage under refrigeration at $5{ }^{\circ} \mathrm{C}$ for 14 days are shown in table 2.

Based on table 2, occurred variation on the average value of $\mathrm{pH}$ over the storage time, being this significant difference $(\mathrm{P} \leq 0,05)$ for $\mathrm{pH}(4.31)$ at 14 days of storage. The $\mathrm{pH}$ reduction and acidity growth are named by after acidification and are resulted by continuous activity of lactic microorganisms, under refrigeration, mainly Lactobacillus, which one the cells have bigger capacity to tolerate acids environments and to produce lactic acid until levels of $1.7 \%$ (ROBINSON et al., 2006). Besides that, it was verified the opposite effect, occurring the growth of $\mathrm{pH}$ during the storage.

According to FRANCO \& LANDGRAF (2008), the increase in $\mathrm{pH}$ may be an indicator of protein biodegradation, resulting in ammonia generation. Thus, the amino acids in the beverage are the main nitrogen source of the bacteria, allowing a large amount of nitrogen compounds (JAY, 2005). In this sense, the degradation of proteins is initiated by the action of enzymes that hydrolyze them to peptides and then to amino acids, since the structure of the intact protein is not able to cross the cell membrane.

The $\mathrm{pH}$ values on dairy drinks have your importance on physical stability related from visual aspect in the final product. Thus, REIS et al. (2013) reported that $\mathrm{pH}$ values bigger than 4.6 favor the syneresis process, because the gel structure is not formed sufficiently. Conversely, if the $\mathrm{pH}$ value is below 4.0, the clot will contract, related to the reduction of protein hydration, causing desorption. In this way, it is fundamental existing a strict $\mathrm{pH}$ control to not occur separation of phase and elevated acidification influenced by fermentation time.

According to table 2, the acidity did not change significantly $(\mathrm{P} \leq 0.05)$ in the average values during the 14 days of storage. ALMEIDA (2008) studying the influence of the reduction of milk lactose content and the increase of protein concentration in the acidification process during fermentation and yogurt storage, observed no influence on $\mathrm{pH}$ variation during storage and that the reduction of lactose content caused that the acidity did not suffer a significant variation, thus avoiding post acidification of the yogurt. Although, the lactose contents were not studied by this research, it can be inferred that, the reduction of lactose in the process of fermentation of the milk beverage, and consequently the production of lactic acid is possibly a cause for the nonsignificant variation of the acidity during the 14 days of refrigerated storage.

According to THAMER \& PENNA (2006), the acidity is related to the concentration of the lactic culture used and the activity of this culture, the value established to finalize the fermentation, type of solid added, to the quantity of cheese serum used in the elaboration of dairy drinks, as well as storage time. Although, do not exist federal legislation specifying $\mathrm{pH}$ and acidity values for fermented dairy drinks, was verified the acidity observed on this study attend the minimum value defined for yoghurt $(0.6$ a $1.5 \mathrm{~g}$ of lactic acid/100 g) and fermented milk ( 0.6 a 2.0 of lactic acid/100 g) established by Fermented Milk Quality Technical Regulation (BRASIL, 2007).

The syneresis and sedimentation results during storage under refrigeration at $5^{\circ} \mathrm{C}$ for 14 days are shown in figure 1. Comparing the mean values obtained for the syneresis index (Figure 1), significant differences $(\mathrm{P} \leq 0.05)$ occurred during storage days. The syneresis values of the beverage ranged from $6.83 \%$ on the first day of manufacture to $25.33 \%$ at 14 days of storage.

According to LUCEY (2004), several factors such as fermentation temperature, often high, low solids content and inadequate storage may

Table 2 - Average $\mathrm{pH}$ and acidity values of the fermented dairy drink as a function of storage time under refrigeration at $5^{\circ} \mathrm{C}$.

\begin{tabular}{lcc}
\hline Time (Days) & $\mathrm{pH}$ & Acidity (\% of lactic acid) \\
0 & $4.18^{\mathrm{a}}$ & $0.81^{\mathrm{a}}$ \\
7 & $4.18^{\mathrm{a}}$ & $0.80^{\mathrm{a}}$ \\
14 & $4.31^{\mathrm{b}}$ & $0.80^{\mathrm{a}}$ \\
$\mathrm{CV}^{*}(\%)$ & 0.30 & 1.17 \\
\hline
\end{tabular}

${ }^{*}$ Coefficient of variation given in percentage $(\%)$. The average followed by different letters in the columns differs from each other $(\mathrm{P} \leq 0.05)$ and refer to the storage time. 


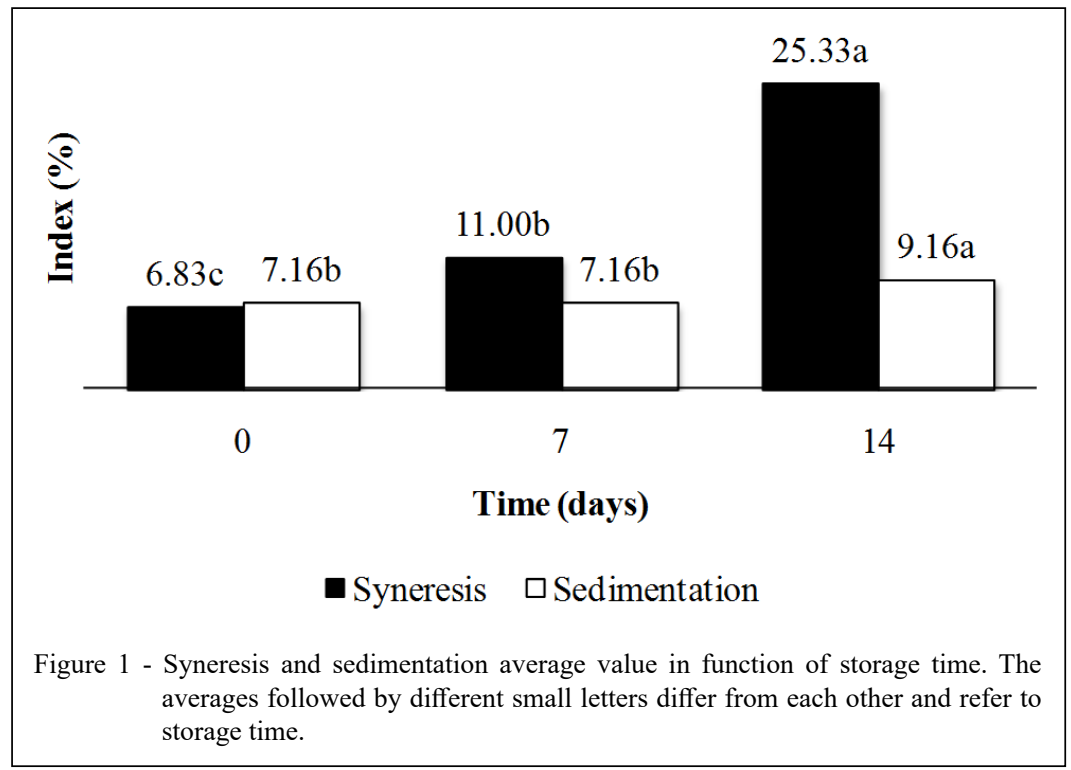

contribute to syneresis in fermented products. Values of 3.5 to $6.7 \%$ syneresis in samples containing 0.5 and $0.65 \%$ of collagen were found by GERHARDT et al. (2013). Conversely, CUNHA (2008) found value of $49 \%$ of syneresis in dairy drink with higher proportion of serum. CASTRO et al. (2009) checked the influence of different contents of cheese whey and oligofructose on fermented dairy drinks proprieties and observed that the increase of cheese whey provided an increase on syneresis index on this beverage. Influence that wasn't observed on this research, once that dairy drink are constitute by an only one formulation and portion of whey.

In agreement to figure 1, there was variation in sedimentation values throughout the storage, but this difference was significant $(\mathrm{P} \leq 0.05)$ only for sedimentation at 14 days of storage $(9.16 \%)$. GERHARDT et al. (2013) obtained sedimentation of about $4.5 \%$ only in samples with 0.5 and $0.65 \%$ of collagen. LUIZ (2008) evaluated the sedimentation in thermally treated milk beverages after fermentation, in their storage at ambient temperature for up to 90 days, verified the non-occurrence of sediments up to 28 days of storage.

Although, several studies present similar and discordant results for syneresis and sedimentation indexes in fermented dairy products, AMATAYAKUL et al. (2006) concluded that the determination of these indexes can present different values and behaviors due to the different methodologies and parameters used by each author.

\section{CONCLUSION}

According the nutritional information, it can be concluded that the elaboration of the fermented dairy milk, added by caja-mango pulp, constitute a food source of many nutrients, being able to be included on complementary feed of children, teenagers and adults, supplying nutritional deficiencies, and thus bringing health benefits to them.

Regarding the physicochemical parameters, even though there is no legislation specifying the $\mathrm{pH}$ and acidity values for the fermented dairy drink, it was found that the acidity meets the minimum value defined for yogurt and fermented milk. As for syneresis and sedimentation rates, these parameters were influenced by the 14 days of storage, under refrigeration at $5 \pm 1{ }^{\circ} \mathrm{C}$, and that, according to the literature, this influence may also be associated with uncontrolled factors in this study. Such as the starter and final milk culture concentration of the elaborated product, protein biodegradation during storage and low solids contents. Thus, future studies are necessary and indispensable to investigate the influence of these factors on the stability of the fermented milk drink and ensure better quality in the final product.

\section{ACKNOWLEDGEMENTS}

This work was realized with the support of the Coordenação de Aperfeiçoamento de Pessoal de Nível Superior (CAPES), Fundação de Amparo à Pesquisa do Estado de Minas Gerais (FAPEMIG), Conselho Nacional de Desenvolvimento 
Científico e Tecnológico (CNPq), Ministério da Educação - Brasil, Universidade Federal de Minas Gerais - UFMG, Pró-Reitoria de Pesquisa da UFMG and Pró-Reitoria de Extensão da UFMG.

DECLARATION OF CONFLICT OF
INTERESTS

The authors declare no conflict of interest. The founding sponsors had no role in the design of the study; in the collection, analyses, or interpretation of data; in the writing of the manuscript, and in the decision to publish the results.

\section{AUTHORS' CONTRIBUTIONS}

All authors contributed equally for the conception and writing of the manuscript. All authors critically revised the manuscript and approved of the final version.

\section{REFERENCES}

ALMEIDA, C. P. M. Efeito do fator de concentração nas características de iogurte com baixo teor de lactose obtido por ultrafiltração. 2008. 47f. Dissertation (Master in Chemical and Biochemical Process Engineering) - Centro Universitário do Instituto Mauá de Tecnologia.

ALMEIDA, K. E. et al. Características físicas e químicas de bebidas lácteas fermentadas e preparadas com soro de Queijo Minas Frescal. Ciência e Tecnologia de Alimentos, v.21, p.187-192, 2001. Available from: <http://www.scielo.br/scielo.php?script=sci artte xt\&pid=S0101-20612001000200012>. Accessed: Feb. 27, 2018. doi: $10.1590 / \mathrm{S} 0101-20612001000200012$.

AMATAYAKUL, T. et al. Syneresis in set yogurt as affected by EPS starter cultures and levels of solids. International Journal of Dairy Technology, v.59, p.216-221, 2006. Available from: <https://onlinelibrary.wiley.com/doi/full/10.11 11/j.1471-0307.2006.00264.x>. Accessed: Mar. 16, 2018. doi: 10.1111/j.1471-0307.2006.00264.x.

AMAYA-LLANO, S. L. et al. Acid thinned jicama and maize starches as fat substitute in stirred yogurt. LWTFood Science and Technology, v.41, p.1274-1281, 2008. Available from: <https:/www.sciencedirect.com/science/ article/pii/S0023643807002848>. Accessed: Feb. 27, 2018. doi: 10.1016/j.1wt.2007.08.012.

BRASIL. Instrução Normativa n. 16, de 23 de agosto de 2005. Regulamento técnico de identidade e qualidade de bebida láctea. Diário Oficial [da] República Federativa do Brasil, Brasília, 24/08/2005, Seção 1, p.7, 2005a.

BRASIL. Instrução Normativa n. 46, de 23 de outubro de 2007. Regulamento Técnico de Identidade e Qualidade de Leites Fermentados. Diário Oficial [da] república Federativa do Brasil, Brasília, 24/10/2007, Seção 1, p.4, 2007.

BRASIL. Instrução Normativa n. 68, de 12 de dezembro de 2006 que adota os Métodos Analíticos Oficiais Físico-químicos para Controle de Leite e Produtos Lácteos. Diário Oficial [da] República Federativa do Brasil, Brasília, 14/12/2006, Seção 1, p.8, 2006.

BRASIL. Resolução RDC n. 269, de 22 de setembro de 2005. Regulamento técnico sobre a ingestão diária recomendada (IDR) de proteína, vitaminas e minerais. Diário Oficial [da] República Federativa do Brasil, Brasília, 23/09/2005, Seção 1, p.372, 2005b.

BRASIL. Resolução RDC n. 360, de 23 de dezembro de 2003. Institui o Regulamento Técnico sobre rotulagem nutricional de alimentos embalados. Diário Oficial [da] República Federativa do Brasil, Brasília, 26/12/2003, Seção 1, p.33, 2003.

BRASIL. Portaria n. 27, de 13 de janeiro de 1998. Aprova o Regulamento Técnico referente à Informação Nutricional Complementar. Diário Oficial [da] República Federativa do Brasil, Brasília, 16/01/1998, Seção 1, 1998.

BUSANELLO, M. P. Development of fermented milk drink with prebiotic caja-manga (Spondias dulcis). 2014. 50f. Monografy (Food Technology Degree) - Universidade Tecnológica Federal do Paraná.

CALDEIRA, L. A. et al. Development of strawberry-flavored milk drink using different yoghurt levels and whey obtained from buffalo's Milk. Ciência Rural, v.40, p.2193-2198, 2010. Available from: <http:/www.scielo.br/scielo.php?script=sci ar ttext\&pid=S0103-84782010001000023>. Accessed: Mar. 16, 2018. doi: 10.1590/S0103-84782010005000176.

CASTRO, F.P. et al. Influence of different content of cheese whey and oligofructose on the properties of fermented lactic beverages: Study using response surface methodology. LWT-Food Science and Technology, v.42, p.993-997, 2009. Available from: $<$ https:// www.sciencedirect.com/science/article/pii/S0023643808003198>. Accessed: Mar. 16, 2018. doi: 10.1016/j.lwt.2008.12.010.

CHEN, Y. et al. Role of calcium in metalloenzymes: effects of calcium removal on the axial ligation geometry and magnetic properties of the catalytic diheme center in MauG. Biochemistry, v.51, p.15861597, 2012. Available from: <https://www.ncbi.nlm.nih.gov/ pubmed/22320333>. Accessed: May, 08, 2019. doi: 10.1021/bi201575f.

CUNHA, T.M. etal. Physico-chemical, microbiological and rheological evaluation of dairy beverage and fermented milk added of probiotics. Semina: Ciências Agrárias, v. 29, p. 103-116, 2008. Available from: $<$ https://www.researchgate.net/publication/276227785_Avaliacao_ fisico-quimica microbiologica e reologica de bebida lactea e leite fermentado adicionados de probioticos $>$. Accessed: Feb. 27, 2018. doi: $10.5433 / 1679-0359.2008 \mathrm{v} 29 \mathrm{n} 1 \mathrm{p} 103$.

FRANCO, B. D. G. M.; LANDGRAF, M. Microbiologia de Alimentos. $1^{\circ}$ ed. São Paulo: Atheneu, 2008. 182p.

DAY, L. Protein: Food Sources. Encyclopedia of Food and Health, AgResearch Ltd., Palmerston North, New Zealand, 2016. Available from: <https://reader.elsevier.com/reader/sd/pii/B9780 123849472005766? token=812D11E60F5E9711AB57E4FD51B DAFCDB816F0A52F108356744402F3E44079C973A2217496 147EB42C78E8ABA64844BD>. Accessed: Nov. 21, 2018. doi: 10.1016/B978-0-12-384947-2.00576-6.

GERHARDT, Â. et al. Características físico-químicas e sensoriais de bebidas lácteas fermentadas utilizando soro de ricota e colágeno hidrolisado. Revista do Instituto de Laticínios Cândido Tostes, v.68, p.41-50, 2013. Available from: <http://www.revistadoilct. com.br/rilct/article/view/7/7>. Accessed: Feb. 27, 2018.

GIACCO, R. et al. Metabolic effects of dietary carbohydrates: The importance of food digestion. Food Research International, v.88, p.336-341, 2016. Available from: <https://www.sciencedirect. 
com/science/article/pii/S0963996915302350>. Accessed: Mar. 18, 2018. doi: 10.1016/j.foodres.2015.10.026.

JANIASKI, D. R. et al. Strawberry-flavored yogurts and whey beverages: What is the sensory profile of the ideal product? Journal of Dairy Science, v.99, p.5273-5283, 2016. Available from: $<$ https:// www.journalofdairyscience.org/article/S0022-0302(16)30216-8/ abstract>. Accessed: Mar. 18, 2018. doi: 10.3168/jds.2015-10097.

JAY, J. M. Microbiologia de alimentos. $6^{\mathrm{a}}$ ed. Porto Alegre: Artmed, 2005. 712p.

KLOSS, L. et al. Sodium intake and its reduction by food reformulation in the European Union - A review. NFS Journal, v.1, p.9-19, 2015. Available from: <https:/www.sciencedirect. com/science/article/pii/S2352364615000024>. Accessed: Nov. 21, 2018. doi: 10.1016/j.nfs.2015.03.001.

LUCA, L. Fats: Nutritional and Physiological Importance. Encyclopedia of Food Security and Sustainability, v.2, p.302306, 2019. Available from: <https://www.sciencedirect.com/ science/article/pii/B9780081005965221434>. Accessed: May, 10, 2019. doi: 10.1016/B978-0-08-100596-5.22143-4.

LUCEY, J. A. Culture dairy products: An overview of their gelation and texture properties. International Journal of Dairy Technology, v.57, p.34-40, 2004. Available from: <http://onlinelibrary.wiley.com/ doi/10.1111/j.1471-0307.2004.00142.x/abstract>. Accessed: Feb. 27, 2018. doi: 10.1111/j.1471-0307.2004.00142.x.

LUIZ, L. M. P. Evaluation of the hot filling of a dairy drink at room temperature conservation. 2008. 70f. Dissertation (Postgraduate in Food Science and Technology) - Universidade Federal de Viçosa.

MONTESDEOCA, R. et al. Procedimiento para la producción de una bebida láctea fermentada utilizando lactosuero. Revista Chilena de Nutrición, v.44, p.3944, 2017. Available from: <https://scielo.conicyt.cl/scielo. php? script $=$ sci_arttext\&pid $=$ S0717-75182017000100006 $>$. Accessed: Mar. 18, 2018.

REIS, J. A. et al. Microbiota contaminante em bebidas lácteas fermentadas comerciais. Revista do Instituto Adolfo Lutz, v.72, p.93-8, 2013. Available from: <http://ses.sp.bvs.br/lildbi/ docsonline/get.php?id=5398>. Accessed: Jan. 18, 2019.

ROBINSON, R. K. et al. Manufacture of yoghurt. In: TAMINE. A.Y. (Ed.) Fermented Milks. Oxford: Blackwell Science, 2006. p.56-70.
RUFINO, M. S. M. Functional properties of non-traditional Brazilian fruits. 2008. 237f. Thesis (Doctorate in plant science) - Universidade Federal Rural do Semi-Árido.

SACRAMENTO, C. K.; SOUZA, F. X. Cajá (Spondias mombin L.). Jaboticabal, Série Frutas Nativas, n. 4, 2000. 42p.

THAMER, K. G.; PENNA, A. L. B. Caracterização de bebidas lácteas funcionais fermentadas por probióticos e acrescidas de prebiótico. Ciência e Tecnologia de Alimentos, v.26, p.589-595, 2006. Available from: <http://www.scielo.br/ scielo.php?pid $=$ S0101-20612006000300017\&script $=$ sci abstract\&tlng=pt>. Accessed: Feb. 27, 2018. doi: 10.1590/ S0101-20612006000300017.

WHITE, D. A. et al. Sunflower-seed oil body emulsions: Rheology and stability assessment of a natural emulsion. Food Hydrocolloids, v.22, p.1224-1232, 2008. Available from: <https://www. sciencedirect.com/science/article/pii/S0268005X07001956>. Accessed: Feb. 27, 2018. doi: 10.1016/j.foodhyd.2007.07.004.

ZHANG, H. et al. Universal Influenza Vaccines, a Dream to Be Realized Soon. Viruses, v.6, p.1974-1991, 2014. Available from: $<$ https://www.ncbi.nlm.nih.gov/pmc/articles/PMC4036552/>. Accessed: May, 08, 2019. doi: 10.3390/v6051974.

ZHANG, H.; ZOWALATY, M. E. El. DNA-based influenza vaccines as immunoprophylactic agents toward universality. Future Microbiology, v.11, p.153-164, 2016. Available from: $<$ https://www.ncbi.nlm.nih.gov/pubmed/26673424>. Accessed: May, 08, 2019. doi: 10.2217/fmb.15.110.

ZHAO, K. et al. Predicting Ca2+ -binding sites using refined carbon clusters. Proteins, v.80, p.2666-2679, 2012. Available from: <https://www.ncbi.nlm.nih.gov/pubmed/22821762>. Accessed: May, 08, 2019.

ZHONG, L. R. et al. Nitric Oxide Regulates Neuronal Activity via Calcium-Activated Potassium Channels. Plos One, v.8, p.e78727, 2013. Available from: <https://journals.plos.org/plosone/ article? $\mathrm{id}=10.1371 /$ journal.pone.0078727 $>$. Accessed: May, 08, 2019. doi: 10.1371/journal.pone.0078727.

ZULUETA, A. et al. Vitamin C, vitamin A, phenolic compounds and total antioxidant capacity of new fruit juice and skim milk mixture beverages marketed in Spain. Food Chemistry, v.103, p.1365-1374, 2007. Available from: <https://www.sciencedirect. com/science/article/pii/S0308814606008363>. Accessed: Feb. 27, 2018. doi: 10.1016/j.foodchem.2006.10.052.
1 